\title{
Penerapan Metode Think Pair Share untuk Meningkatkan Keterampilan Menulis Iklan Baris
}

\author{
Suntoro(1) \\ ${ }^{1}$ SMP Negeri 4 Tulungagung
}

\begin{abstract}
ABSTRAK
Dalam rangka meningkatkan Ketrampilan Menulis Bahasa Indonesia yang memuat Menulis Iklan Baris pada Siswa Kelas IX A SMP Negeri 4 Tulungagung, Peneliti melakukan penelitian tindakan kelas dengan menerapkan pendekatan Think Pair Share pada pembelajaran Bahasa Indonesia. Sasaran penelitian ini adalah siswa Kelas IX A SMP Negeri 4 Tulungagung yang berjumlah 30 siswa. Berdasarkan hasil observasi yang dilakukan di Kelas IX A pada waktu pembelajaran Bahasa Indonesia diperoleh hasil bahwa Ketrampilan Menulis siswa kurang memuaskan, yaitu dari 30 siswa hanya 10 siswa yang nilainya dapat mencapai KKM atau $\geq 70$, sedangkan 20 siswa lainnya masih belum dapat mencapai KKM atau $\leq 69$. Simpulan dari penelitian ini adalah pendekatan Think Pair Share dapat meningkatkan Ketrampilan Menulis siswa pada pembelajaran Bahasa Indonesia yang memuat Menulis Iklan Baris.
\end{abstract}

\section{Kata kunci: Hasil belajar, Operasi Bilangan Berpangkat, Smart Games.}

\section{PENDAHULUAN}

Pelajaran Bahasa Indonesia terdapat kompetensi dasar menulis iklan baris dengan bahasa yang singkat, padat, dan jelas. Tujuan pembelajaran tersebut adalah siswa dapat mendaftar butir-butir yang akan dituliskan dalam iklan baris di surat kabar dan dapat menulis iklan baris dengan bahasa yang hemat. Indikator keberhasilannya yang diharapkan adalah (1) Mampu menentukan objek yang akan diiklankan; (2) Mampu menyingkat kata-kata sesuai dengan kebiasaan iklan baris; (3) Mampu menulis iklan baris dengan bahasa yang singkat, padat, dan jelas; (4) Mampu menyunting iklan baris

Dari informasi yang di peroleh dari guru Bahasa Indonesia di SMP Negeri 4 Tulungagung, pembelajaran Bahasa Indonesia yang selama ini sudah dilaksanakan di SMP Negeri 4 Tulungagung menggunakan Metode ceramah yang terkadang diselingi dengan diskusi kelompok (pembelajaran kooperatif) dan masih menerapkan keaktifan guru dalam kegiatan pembelajarannya. Pembelajaran cenderung bersifat informatif sehingga keterlibatan siswa secara aktif dalam proses pembelajaran masih kurang. Kondisi yang demikian akan membuat siswa kurang termotivasi untuk belajar. Hal ini terbukti dengan perilaku siswa yang kurang bersemangat dalam mengikuti kegiatan belajar di kelas sehingga nilai siswa pada mata pelajaran Bahasa Indonesia kurang memuaskan. Agar tujuan pembelajaran Bahasa Indonesia di SMP dapat dicapai maka perlu adanya inovasi dalam proses pembelajaran Bahasa Indonesia di kelas. Inovasi tersebut dapat berupa model pembelajaran yang bisa membuat siswa menjadi lebih aktif dan bersemangat dalam melakukan proses pembelajaran.

Dalam proses pembelajaran di kelas sering timbul masalah yang pada umumnya dialami oleh siswa. Masalah yang dihadapi siswa bersifat unik berbeda satu sama lain. Misalnya masalah dan kesulitan ataupun rendahnya Ketrampilan Menulis yang dialami siswa pada mata pelajaran Bahasa Indonesia bisa terjadi karena berbagai faktor diantaranya, keterbatasan kemampuan, keadaan, minat dan motivasi diri siswa itu sendiri, situasi belajar di sekolah atau kelas dan kurangnya sarana dan prasarana, materi pelajaran yang kurang relevan dengan kebutuhan siswa dan pendekatan mengajar yang kurang bisa dipahami siswa bahkan kurangnya alat peraga dan alat bantu mengajar.

Apalagi mata pelajaran Bahasa Indonesia menuntut kemampuan Guru untuk bisa membuat siswa mengerti dan memahami tentang materi yang diajarkan dengan 
Vol. 1 No. 1, Oktober 2017

tidak hanya membaca buku dan teori saja melainkan harus disertai alat peraga, contoh, praktek, latihan soal, seperti soal bercerita dan sebagainya, agar siswa memiliki pengetahuan, keterampilan dan bahkan sikap ilmiah yang berujung pada pemerolehan Ketrampilan Menulis yang maksimal..

Berdasarkan hasil pengamatan dalam proses belajar mengajar dikelas, keadaan sekolah, dan melalui peninjauan bidang akademik dan non akademik, diperoleh hasil bahwa keadaan Sekolah Menengah Pertama SMP Negeri 4 Tulungagung khususnya siswa Kelas IX A tahun pelajaran 2016/2017 dalam pelajaran Bahasa Indonesia belum menunjukkan Ketrampilan Menulis sesuai dengan KKM yang ditetapkan terutama pada materi pelajaran Menulis Iklan Baris. Padahal, ditinjau dari keadaan fisik sekolah, yaitu ruang Kelas IX A sudah baik dan sesuai sebagai tempat berlangsungnya proses belajar mengajar. Pengamatan pada proses pembelajaran oleh peneliti dapat disimpulkan bahwa pelaksanaan proses belajar mengajar lah yang belum membuat siswa aktif belajar, sehingga kemampuan siswa belum tergali dengan maksimal.

Pada ulangan harian Bahasa Indonesia dengan materi Menulis Iklan Baris, di dapat rata-rata nilai sebesar 65,2 dari 30 siswa, padahal Kriteria Ketuntasan Minimalnya (KKM) telah ditentukan nilai sebesar 70. Dan hanya 10 siswa yang mendapat nilai di atas 70 . Hal ini berarti, hanya $33,3 \%$ dari siswa yang telah mencapai ketuntasan belajar, dan yang lainnya memiliki Ketrampilan Menulis yang rendah.

Dari hasil diskusi dengan teman sejawat ditemukan masalah-masalah dalam proses pembelajaran Bahasa Indonesia yang menyebabkan menurunkan Ketrampilan Menulis adalah materi kurang dapat dikuasi siswa secara optimal, penggunaan pendekatan pembelajaran dalam pembelajaran Bahasa Indonesia pada siswa Kelas IX A belum sesuai, siswa terlihat tidak antusias untuk belajar dan pembelajaran dengan pendekatan konvensional yaitu dengan menjelaskan materi dan siswa hanya melakukan perintah mengerjakan soal tanpa penanaman konsep pembelajaran yang kuat terlihat tidak efektif dalam proses peningkatan Ketrampilan Menulis siswa.

Oleh karena itu, demi memperbaiki berbagai masalah yang ada, peneliti memerlukan suatu solusi untuk mengatasi hambatan-hambatan yang terjadi, peneliti menggunakan pendekatan Think Pair Share dalam pembelajaran Bahasa Indonesia ini. Strategi Think Pair Share dimaksudkan sebagai alternatif terhadap struktur kelas tradisional seperti resitasi, dimana guru mengajukan pertanyaan kepada seluruh siswa dan siswa memberikan jawaban setelah mengangkat tangan dan ditunjuk. Strategi ini menantang asumsi bahwa seluruh resitasi dan diskusi perlu dilakukan di dalam lingkungan seluruh kelompok.

Penerapan model pembelajaran Think-Pair-Share diharapkan siswa dapat mengembangkan keterampilan berfikir dan menjawab dalam komunikasi antara satu dengan yang lain, serta bekerja saling membantu dalam kelompok kecil.

Rumusan masalah dari penelitian ini adalah Bagaimana penerapan pendekatan Think Pair Share untuk meningkatkan Ketrampilan Menulis Bahasa Indonesia penguasaan Menulis Iklan Baris pada Siswa Kelas IX A SMP Negeri 4 Tulungagung?

Apakah penerapan pendekatan Think Pair Share dapat meningkatkan Ketrampilan Menulis Bahasa Indonesia materi Menulis Iklan Baris pada Siswa Kelas IX A SMP Negeri 4 Tulungagung?

Tujuan dari penelitian ini adalah mendeskripsikan penerapan Pendekatan Think Pair Share pada Siswa Kelas IX A SMP Negeri 4 Tulungagung, dan meningkatkan Ketrampilan Menulis siswa pada Bahasa Indonesia yang memuat Menulis Iklan Baris melalui penerapan Pendekatan Think Pair Share pada Siswa Kelas IX A SMP Negeri 4 Tulungagung.

Dalam pelaksanaan penelitian ini, peneliti berharap dapat memberikan manfaat bagi: 1) Peneliti (Guru) adalah (a) Sebagai saranan peningkatan mutu, ilmu pengetahuan, pendekatan dan seni mengajar (b) Sebagai jembatan bagi Guru agar lebih mudah berkomunikasi dengan siswa (c) Sebagai acuan dan bahan tinjauan 
dalam pembinaan dan penilaian terhadap Proses Belajar Mengajar (PBM) yang dilaksanakan Guru di sekolah (d) Hasil penelitian ini dapat dijadikan sebagai masukan untuk meningkatkan mutu dan kualitas pembelajaran di kelas. (2) Manfaat penelitian ini bagi siswa adalah: (a) Siswa dapat lebih mudah memahami materi pelajaran (b) Siswa lebih berani dalam bereksperimen dan menemukan hal baru (c) Dapat meningkatkan kemampuan siswa dalam menerima pembelajaran sehingga Ketrampilan Menulis siswa pun menjadi lebih baik. (3) Manfaat penelitian ini bagi peneliti lain adalah hasil penelitian dapat dijadikan acuan dalam melakukan penelitian yang sejenis dan (4) Manfaat penelitian ini bagi kepala sekolah adalah hasil penelitian ini dapat dijadikan acuan dalam membuat kebijakan tentang peningkatan kualitas sekolah.

\section{METODE \\ Subjek, Tempat dan Waktu Penelitian}

Lokasi yang digunakan tempat penelitian adalah ruang Kelas IX A Sekolah Menengah Pertama SMP Negeri 4 Tulungagung Tahun Pelajaran 2016/2017. Dalam penelitian ini subjek yang digunakan adalah seluruh siswa Kelas IX A Sekolah Menengah Pertama SMP Negeri 4 Tulungagung sebanyak 30 siswa yang terdiri dari 18 siswa putra dan 12 siswa putri.

Penelitian dilaksanakan pada semester 1, adapun pada siklus pertama dilaksanakan pada hari Rabu, 7 September 2016 dan siklus kedua dilaksanakan pada hari Rabu, 14 September 2016.

\section{Desain Prosedur Perbaikan Pembelajaran}

Penelitian ini menggunakan pendekatan penelitian kualitatif dengan pendekatan penelitian tindakan kelas karena penelitian ini dilaksanakan berdasarkan adanya temuan masalah di kelas. Berdasarkan variable yang diteliti dan tujuan yang hendak dicapai, maka pendekatan penelitian yang digunakan adalah dengan sistem spiral. Stephen Kemmis dan Robin Mc Taggart tahun 1988 mengembangkan model Kurt Lewin dalam suatu sistem spiral dengan empat komponen utama, yakni perencanaan (planning), tindakan (acting), observasi (observing) dan refleksi (reflecting). Tahap pelaksanaan tindakan yaitu merupakan suatu hal yang dilakukan sebagai upaya perubahan yang dilakukan. Tahap observasi atau pengamatan yaitu mengamati secara sistematis hasil atau dampak tindakan terhadap proses belajarmengajar, dan tahap refleksi yaitu mengkaji dan mempertimbangkan hasil atau dampak tindakan yang dilakukan.

Peneliti dalam penelitian kualitatif berperan sebagai instrument penelitian, kehadiran peneliti mutlak diperlukan, dalam hal ini peneliti bertindak sebagai perencana, pelaksanaan pengajaran, pengumpul data, penganalisis, penafsir dan sebagai pelapor hasil penelitian. Peneliti berkolaborasi dengan teman sejawat sebagai observer. Penelitian ini bertempat di SMP Negeri 4 Tulungagung. SMP Negeri ini termasuk lembaga pendidikan yang memiliki hasil output bagus dilingkup sekitarnya. Namun terlihat nilai pembelajaran Bahasa Indonesia di Kelas IX A belum maksimal, Guru lebih banyak berceramah, siswa hanya sebagai pendengar, kondisi seperti ini mengakibatkan siswa merasa bosan dan enggan belajar Bahasa Indonesia dan susah dalam mengerjakan soal-soal Bahasa Indonesia khususnya Menulis Iklan Baris. Selain itu, dilihat bahwa nilai Bahasa Indonesia siswa masih belum menggembirakan karena masih terdapat siswa yang nilainya berada di bawah KKM. Dalam pelaksanaan Penelitian Perbaikan Pembelajaran ini yang akan menjadi subjek adalah Siswa Kelas IX A SMP Negeri 4 Tulungagung, yang berjumlah 30 siswa.

Berdasarkan hasil pengidentifikasian dan penetapan masalah, peneliti kemudian mengajukan suatu solusi yang berupa penerapan Pendekatan Think Pair Share yang dapat dimanfaatkan Guru untuk digunakan sebagai pendekatan pengajaran dalam pembelajaran Bahasa Indonesia Kelas IX A SMP Negeri 4 Tulungagung. Penelitian ini dilakukan dengan dua siklus, dimana masing-masing siklus dikenai perlakuan yang sejenis dengan bobot yang beda. Dibuat dua siklus 
dimaksudkan untuk memperbaiki system pengajaran yang dilaksanakan.. Pelaksanaan tindakan pada siklus 1 dan siklus 2 dibagi menjadi 4 tahapan yaitu (1) Persiapan awal, (2) pertemuan awal, (3) proses supervisi (observasi), dan (4) pertemuan balikan atau refkleksi.

Pengumpulan data dalam penelitian ini dapat dilakukan dengan menggunakan teknik observasi, angket, dokumentasi, tes, wawancara, dan catatan lapangan. Teknik analisis data yang digunakan dalam penelitian ini adalah teknik analisis data kualitatif yaitu menggambarkan kenyataan atau data sesuai dengan data yang diperoleh dengan tujuan untuk mengetahui peningkatan kualitas kinerja guru. Langkah-langkah analisis terdiri dari tiga alur kegiatan yang terjadi secara bersamaan yaitu: (1) reduksi data, (2) penyajian data, (3) penarikan kesimpulan.

Pada kegiatan reduksi data, peneliti mengumpulkan pelaksanaan pengembangan pembelajaran menggunakan pendekatan Think Pair Share dan Ketrampilan Menulis siswa Data hasil reduksi yaitu pelaksanaan pengembangan pembelajaran menggunakan pendekatan Think Pair Share pada siklus 1 dan 2, data hasil observasi Guru pada siklus 1 dan siklus 2. Kegiatan penyajian data dilakukan dalam rangka mengorganisasikan hasil reduksi, dengan menyusun secara narasi sekumpulan informasi yang diperoleh dari hasil reduksi hingga memberi kemungkinan adanya penarikan kesimpulan dan pengambilan tindakan. Informasi yang dimaksud adalah apakah penerapan pendekatan Think Pair Share dapat meningkatkan Ketrampilan Menulis siswa, Pengelolaan pembelajaran oleh Guru, respon siswa terhadap kegiatan pembelajaran, serta hasil yang diperoleh sebagai akibat dari pemberian tindakan. Sajian data selanjutnya ditafsirkan dan dievaluasi untuk merencanakan tindakan selanjutnya.

\section{Teknik Analisis Data}

Teknik analisis yang digunakan yaitu deskriptif persentase. Data hasil penelitian yang dianalisis meliputi rata-rata kelas, ketuntasan belajar individu dan ketuntasan belajar secara klasikal. Selanjutnya hasil analisis data diperoleh baik secara kualitatif (dengan kata-kata) dan kuantitatif (dengan grafik). Hasil ini diinterprestasikan dan disimpulkan untuk menjawab permasalahan yang ada

Kegiatan penarikan kesimpulan mencakup pencarian arti dan makna data serta memberi penjelasan. Makna dan arti yang diperoleh tersebut harus di uji kebenarannya serta kecocokannya melalui kegiatan verifikasi. Verifikasi tersebut merupakan validitas data yang disimpulkan. Hasil analisis data ini akan dijadikan dasar untuk menentukan keberhasilan pemberian tindakan. Selain itu analisis data ini akan digunakan dasar untuk melaksanakan tindakan selanjutnya, jika pemberian tindakan sebelumnya tidak berhasil. Berdasarkan analisis maka akan ditentukan mana yang perlu dilakukan perbaikan untuk pelaksanaan tindakan selanjutnya. Penarikan kesimpulan dilihat dari hasil ketuntasan belajar siswa baik secara individu maupun kelompok selama pembelajaran dengan menggunakan pengembangan pendekatan Think Pair Share.

Patokan penilaian yang digunakan adalah target indikator pencapaian persentase target ketercapaian pada indikator yang ditetapkan dalam penelitian ini berdasarkan pada hasil observasi yang dilakukan baik pra siklus, siklus 1 ataupun siklus 2, dikatakan indikator tercapai bila $85 \%$ dari siswa Kelas IX A mendapat nilai Bahasa Indonesia minimal di atas KKM atau 70

Evaluasi dilaksanakan setelah diperoleh hasil analisis yang akurat. Kegiatan evaluasi dilakukan untuk mengetahui keberhasilan penelitian dalam meningkatkan Ketrampilan Menulis siswa melalui pembelajaran menggunakan pendekatan Think Pair Share pada pembelajaran Bahasa Indonesia materi Menulis Iklan Baris, jika hasil penelitian belum sesuai dengan harapan, maka akan dicari penyebabnya. Untuk itu dalam penelitian juga diperlukan refleksi. Refleksi merupakan kegiatan memikirkan atau merenungkan kembali semua kegiatan yang telah dilakukan, kemudian mencari 
solusi perbaikan yang dapat dilakukan untuk meningkatkan keberhasilan tindakan yang dilakukan.

\section{HASIL \\ Paparan Data Observasi Pra Siklus}

Sebelum melaksanakan proses penelitian, peneliti mengumpulkan data dan informasi tentang subjek penelitian. Data-data yang dikumpulkan antara lain daftar nama siswa Kelas IX A, daftar nilai ulangan harian Bahasa Indonesia materi Menulis Iklan Baris, hasil wawancara dengan informan yaitu siswa Kelas IX A SMP Negeri 4 Tulungagung. Dari pengumpulan data, nilai ulangan harian tentang Menulis Iklan Baris, rata-rata nilai yang didapat hanya sebesar 65,2. Dari 30 siswa, hanya 10 siswa yang mendapat nilai di atas 70 . Ini berarti hanya $33,3 \%$ siswa yang telah mencapai ketuntasan belajar, karena Kriteria Ketuntasan Minimal (KKM) telah ditentukan sebesar 70.

Daftar frekuensi nilai ulangan harian Bahasa Indonesia Menulis Iklan Baris siswa Kelas IX A SMP Negeri SMP Negeri 4 Tulungagung pada kondisi awal adalah 2 siswa atau $6.7 \%$ yang mendapat nilai antara 0 - 40, ada 18 siswa atau $60.0 \%$ yang mendapat nilai antara 41 - 69, dan ada 10 siswa atau 33,3\%yang mendapat nilai antara 70 - 100. Dengan ketentuan nilai KKM 70, maka dapat disimpulkan jika pencapaian prestasi nilai 70 - 100 yang hanya 33,3\% merupakan prestasi yang rendah.

Selain itu, dari proses wawancara diperoleh kesimpulan bahwa siswa kurang berminat dalam melaksanakan kegiatan pembelajaran, serta dalam pembelajaran Guru lebih sering menggunakan ceramah sehingga siswa merasa jenuh dan bosan, akibatnya minat siswa untuk belajar Bahasa Indonesia terutama pada Menulis Iklan Baris menjadi berkurang sehingga mempengaruhi hasil prestasinya

Berdasarkan hasil data yang dikumpulkan, dapat dikemukakan dua hal pokok yang perlu diatasi, yaitu menumbuhkan minat siswa untuk belajar Bahasa Indonesia dan memahamkan Menulis Iklan Baris dengan cara mengaktifkan siswa dalam kegiatan belajar mengajar dan meningkatkan Ketrampilan Menulis siswa dengan menerapkan Pendekatan Think Pair Share pada siklus 1 nanti dengan harapan Ketrampilan Menulis siswa dapat meningkat. Untuk itu perlu dilaksanakan perbaikan pembelajaran pada siklus 1 dan jika belum tuntas maka akan dilanjutkan pada siklus 2 .

\section{Tinjauan Siklus 1}

Pelaksanaan siklus I yang dilaksanakan pada hari Rabu tanggal 7 September 2016 di ruang Kelas IX A SMP Negeri 4 Tulungagung pada jam pertama dan kedua. Pertemuan direncanakan berlangsung $2 \times 40$ menit dilaksanakan pada jadwal terstruktur. Proses belajar mengajar mengacu pada rencana pembelajaran yang telah dipersiapkan.

Langkah peneliti antara lain adalah menyiapkan instrument penelitian, dan bahan ajar salah satunya Rencana Pelaksanaan Pembelajaran Siklus I materi pelajaran Bahasa Indonesia Kelas IX A semester 1, dengan Kompetensi Dasar 4.1 Menulis iklan baris dengan bahasa yang singkat, padat dan jelas. Serta indikator 4.1.1 Menuliskan objek yang diiklankan dengan ,4.1.2 Menggunakan kata-kata yang sesuai dengan kebiasaan iklan baris. Mempersiapkan pula silabus, materi pelajaran, tugas kelompok atau lembar kegiatan, post test. Peneliti juga menyiapkan evaluasi, evaluasi digunakan peneliti untuk mengukur sejauh mana keberhasilan proses pembelajaran. Peneliti pun menyiapkan lembar observasi, untuk mengamati proses pembelajaran dan lembar angket untuk mengetahui hasil pendekatan pembelajaran.

Kegiatan diawali dengan menjelaskan tentang pendekatan yang akan digunakan yaitu Pendekatan Think Pair Share dan komponen-komponennya kepada siswa. Guru membuka pelajaran dengan mengucapkan salam. Guru memberikan apersepsi kalimat Menulis Iklan Baris, "Anak-anak siapa yang pernah membaca iklan pada kolom tersediri yang terdapat di koran? Bagaimankah bentuk iklan tersebut?" 
Vol. 1 No. 1, Oktober 2017

Setelah itu, siswa dibagi ke dalam 6 (enam) kelompok sesuai absensi, setelah itu Guru atau Peneliti memberikan penjelasan tentang tujuan pembelajaran dan garis besar Bahasa Indonesia tentang menulis iklan baris.

Setelah siswa bergabung ke dalam kelompoknya masing-masing. Guru atau Peneliti membagi tugas kepada setiap kelompok. untuk menganalisis menganalisis iklan baris.

Dalam pelaksanaan kegiatan mengerjakan lembar kerja siswa, Guru memberi bimbingan. Secara berkelompok, siswa berdiskusi dalam menyatukan dan menemukan anggota tubuh dan kegunaannya. Pelaksanaan percobaan ini sebagai penerapan awal Metode Think pair share digunakan untuk menguji jawaban sementara)

Setelah kegiatan kelompok selesai, dilanjutkan dengan diskusi kelas yang dipandu oleh Guru untuk membahas hal-hal yang tidak atau belum terselesaikan dalam kegiatan kelompok. Guru secara bergilir mendekati masing-masing kelompok untuk memberikan penguat serta penjelasan sesuatu hal yang belum dipahami oleh siswa (Kegiatan diskusi adalah kegiatan Metode Think pair share menarik kesimpulan)

Guru atau peneliti membacakan hasil diskusi di depan kelas. Guru berperan sebagai moderator untuk membantu siswa menanggapi hasil presentasi hasil diskusi, atas perintah Guru, kemudian salah satu siswa perwakilan dari masing-masing kelompok melaporkan hasil diskusinya dimuka, siswa yang lain memperhatikan. Guru memberikan ulasan terhadap materi yang belum tersentuh oleh kerja kelompok siswa, serta memberikan ulasan terhadap materi yang belum tersentuh oleh kerja kelompok siswa Secara bersama-sama, Guru mengambil simpulan dan mendiskusikannya bersama siswa. Guru memberikan post tes atau quis untuk mengukur keberhasilan yang dicapai siswa. (lembar soal dapat dilihat di lampiran). Sehingga bisa dilihat peningkatan Ketrampilan Menulisnya.

Berdasarkan penilaian Observasi Siklus 1 didapatkan hasil observasi pada table berikut:

\begin{tabular}{|c|l|c|}
\hline No & \multicolumn{1}{|c|}{ Kegiatan Siswa } & Prosentase \\
\hline 1 & Kelengkapan menyiapkan alat dan bahan percobaan & $60 \%$ \\
\hline 2 & $\begin{array}{l}\text { Keruntutan langkah-langkah dalam pelaksanaan kegiatan } \\
\text { percobaan }\end{array}$ & $65 \%$ \\
\hline 3 & Keaktifan siswa selama melaksanakan kegiatan percobaan & $70 \%$ \\
\hline 4 & Keaktifan siswa dalam mengutarakan pendapat saat berdiskusi & $68 \%$ \\
\hline 5 & Kesimpulan akhir sesuai percobaan & $66 \%$ \\
\hline
\end{tabular}

Adapun hasil post test siklus pertama adalah :

\begin{tabular}{|c|l|c|}
\hline No & \multicolumn{1}{|c|}{ Deskripsi } & Nilai \\
\hline 1 & Jumlah Nilai & 2195 \\
\hline 2 & Rata-rata Hasil Post Test & 73,2 \\
\hline 3 & Jumlah siswa yang mendapat nilai diatas KKM (70) & 19 \\
\hline 4 & Presentase siswa yang mendapat nilai diatas KKM (70) & $63,3 \%$ \\
\hline 5 & Jumlah siswa yang mendapat nilai dibawah KKM (70 & 11 \\
\hline 6 & Presentase siswa yang mendapat nilai dibawah KKM (70) & $36,7 \%$ \\
\hline
\end{tabular}

Dari table tersebut terdapat 11 siswa atau $36,7 \%$ yang mendapat nilai antara 41 - 69, dan 19 siswa atau 63,30\% yang mendapat nilai antara $70-100$. Dengan ketentuan nilai KKM 70, dapat disimpulkan jika pencapaian prestasi nilai $70-100$, maka prestasi belajar siswa telah meningkat dari 33,3\% menjadi $63,3 \%$. Namun karena belum mencapai target indicator pencapaian siklus I sebesar $85 \%$ atau lebih, maka akan dilanjutkan ke Siklus II.

Selain itu, dari proses wawancara diperoleh kesimpulan bahwa beberapa siswa menjadi bersemangat dalam belajar Bahasa Indonesia, karena pelaksanaan kegiatan belajar Bahasa Indonesia dengan Pendekatan Think Pair Share ini dilaksanakan dengan langsung secara mandiri oleh siswa, dan melaksanakan kegiatan 
bersama kelompok sehingga lebih ringan. Meskipun masih terdapat kendala-kendala seperti yang telah diuraikan dalam laporan observasi.

Tinjauan Siklus 2

Berdasarkan hasil refleksi pada siklus I, disepakati bahwa siklus kedua perlu dilaksanakan. Pelaksanaan siklus II yang dilaksanakan pada hari Rabu, tanggal 14 September 2016 di SMP Negeri 4 Tulungagung pada jam pertama dan kedua. Pertemuan direncanakan berlangsung 2x40 menit dilaksanakan pada jadwal terstruktur. Proses belajar mengajar mengacu pada rencana pembelajaran yang telah dipersiapkan. Pengamatan (observasi) dilaksanakan bersamaan dengan pelaksaaan belajar mengajar.

Pada siklus 2 ini, Guru lebih memperhatikan dan mendekati siswa dan kelompok yang memerlukan bimbingan, Guru memberi bimbingan bagi siswa dan kelompok yang memerlukan, Guru memandu siswa dalam melaksanakan percobaan, Karena pada siklus I diketahui masih banyak siswa yang malu untuk maju presentasi dan mengajukan pertanyaan, maka pada siklus II ini Guru memberikan reward kepada siswa yang mau maju presentasi dan aktif dalam diskusi baik bertanya maupun menjawab pertanyaan.

Langkah peneliti antara lain adalah menyiapkan instrument penelitian, dan bahan ajar salah satunya Rencana Pelaksanaan Pembelajaran Siklus II Mata pelajaran Bahasa Indonesia Kelas IX A semester 1, dengan Kompetensi Dasar 4.1 Menulis iklan baris dengan bahasa yang singkat, padat dan jelas. Serta indikator 4.1.1 Menuliskan objek yang diiklankan dengan ,4.1.2 Menggunakan kata-kata yang sesuai dengan kebiasaan iklan baris. Mempersiapkan pula silabus, materi pelajaran, tugas kelompok atau lembar kegiatan, post test. Peneliti juga menyiapkan evaluasi soal, evaluasi digunakan peneliti untuk mengukur sejauh mana keberhasilan proses pembelajaran. Peneliti pun menyiapkan lembar observasi, untuk mengamati proses pembelajaran dan lembar angket untuk mengetahui hasil pendekatan pembelajaran

Langkah-langkah yang dilakukan Guru dalam pelaksanaan siklus II ini antara lain, kegiatan diawali dengan Guru membuka pelajaran dengan mengucapkan salam; Guru mengulang materi yang lampau yang berkaitan dengan materi yang akan disampaikan sekarang; Memberikan apersepsi, soal pemanasan untuk siswa seperti Anak-anak Apakah ciri-ciri iklan baris?"

Menjelaskan kembali tentang Metode yang akan digunakan yaitu Metode Think Pair Share dan komponen-komponennya kepada siswa. Siswa menuju kelompoknya masing-masing, setelah itu Guru atau peneliti memberikan penjelasan lagi tentang tujuan pembelajaran dan garis besar Menulis Iklan Baris.

Menjelaskan kembali tentang metode yang akan digunakan yaitu Model Pembelajaran Think Pair Share serta komponen-komponennya kepada siswa. Siswa menuju kelompoknya masing-masing, setelah itu Guru atau peneliti memberikan penjelasan lagi tentang tujuan pembelajaran dan garis besar Menulis Iklan Baris.

Setelah siswa bergabung ke dalam kelompknya masing-masing. Guru membagikan lembar kegiatan yang berisi petunjuk pelaksanaan percobaan untuk penemuan, kemudian menugaskan siswa untuk melaksanakannya (lihat lampiran). Dalam pelaksanaan kegiatan mengerjakan lembar kerja siswa, Guru memberi bimbingan. Siswa melaksanakan kegiatan percobaan sesuai lembar kegiatan, (lihat lampiran). (1) Dalam satu kelompok terdiri dari 5 orang. (2) Siswa berdiskusi untuk menulis sebuah iklan baris dengan benar. (3) Hasil karya dipajang di dinding kelas. (4) Pelaksanaan percobaan ini sebagai penerapan kedua dan digunakan untuk menguji jawaban kelemahan siklus I).

Setelah kegiatan kelompok selesai, dilanjutkan dengan diskusi kelas yang dipandu oleh Guru untuk membahas hal-hal yang tidak atau belum terselesaikan dalam kegiatan kelompok. Selama siswa berdiskusi, Guru secara bergilir mendekati masing-masing kelompok untuk memberikan penguat serta penjelasan sesuatu hal 
yang belum dipahami oleh siswa. (Kegiatan diskusi adalah kegiatan Pendekatan Think Pair Share menarik kesimpulan).

Guru atau peneliti membacakan hasil diskusi di depan kelas. Guru berperan sebagai moderator untuk membantu siswa menanggapi hasil presentasi hasil diskusi. Guru memberikan ulasan terhadap materi yang belum tersentuh oleh kerja kelompok siswa, serta memberikan ulasan terhadap materi yang belum tersentuh oleh kerja kelompok siswa. Sebagai perbaikan siklus I, Guru memberikan reward kepada siswa yang aktif dalam diskusi dan Think Pair Share. Dengan iming-iming reward yang ditawarkan Guru, banyak dari siswa menjadi aktif dalam diskusi dan bertanya ataupun mengungkapkan pendapatnya, bahkan di antara kelompok mereka saling berdebat dengan positif. Secara bersama-sama, Guru mengambil simpulan dan mendiskusikannya bersama siswa. Guru memberikan post tes atau quis untuk mengukur keberhasilan yang dicapai siswa.

Adapun prosentase hasil observasi dalam pelaksanaan percobaan pada siklus II dapat dilihat dari tabel bawah ini:

\begin{tabular}{|c|l|c|}
\hline No & \multicolumn{1}{|c|}{ Kegiatan Siswa } & Prosentase \\
\hline 1 & Kelengkapan menyiapkan alat dan bahan percobaan & $80 \%$ \\
\hline 2 & $\begin{array}{l}\text { Keruntutan langkah-langkah dalam pelaksanaan kegiatan } \\
\text { percobaan }\end{array}$ & $90 \%$ \\
\hline 3 & Keaktifan siswa selama melaksanakan kegiatan percobaan & $90 \%$ \\
\hline 4 & Keaktifan siswa dalam mengutarakan pendapat saat berdiskusi & $88 \%$ \\
\hline 5 & Kesimpulan akhir sesuai percobaan & $87 \%$ \\
\hline
\end{tabular}

Hasil post test pada siklus kedua dapat menjadi perhitungan persentase peningkatan Ketrampilan Menulis siswa. Dengan acuan penilaian tetap berdasarkan nilai KKM yang telah ditetapkan yaitu paling sedikit siswa memperoleh nilai 70 . Adapun rekapitulasi hasil test siklus II adalah sebagai berikut:

\begin{tabular}{|c|l|c|}
\hline No & \multicolumn{1}{|c|}{ Deskripsi } & Nilai \\
\hline 1 & Jumlah Nilai & 2462 \\
\hline 2 & Rata-rata Hasil Post Test & 82,1 \\
\hline 3 & Jumlah siswa yang mendapat nilai diatas KKM (70) & 28 \\
\hline 4 & Presentase siswa yang mendapat nilai diatas KKM $(70)$ & $93,3 \%$ \\
\hline 5 & Jumlah siswa yang mendapat nilai dibawah KKM (70 & 2 \\
\hline 6 & Presentase siswa yang mendapat nilai dibawah KKM $(70)$ & $6,7 \%$ \\
\hline
\end{tabular}

Dari table di atas diketahui terdapat 2 siswa atau 6,7\% yang mendapat nilai antara 41 - 69, dan 28 siswa atau 93,3\% yang mendapat nilai antara 70 - 100 . Dengan ketentuan nilai KKM 70, dapat disimpulkan jika pencapaian prestasi nilai 70 100 , maka prestasi belajar siswa telah meningkat dari $60 \%$ menjadi $93,3 \%$. Dengan $93,3 \%$ maka telah tercapai indicator pencapaian siklus II sebesar yang $85 \%$ atau lebih, maka tidak perlu dilanjutkan ke Siklus III.

Selain itu, dari proses wawancara diperoleh kesimpulan bahwa beberapa siswa menjadi bersemangat dalam belajar Bahasa Indonesia, karena pelaksanaan kegiatan belajar Bahasa Indonesia dengan pendekatan Think Pair Share ini dilaksanakan dengan melibatkan masing-masing anggota kelompok, dan didiskusikan bersama kelompok sehingga mereka lebih rileks dan ringan dalam mengerjakan laporan kegiatan. Meskipun masih terdapat kendala-kendala seperti yang telah diuraikan dalam laporan observasi

\section{PEMBAHASAN}

Berdasarkan hasil pelaksanaan pada siklus I, II dapat dinyatakan bahwa terjadi peningkatan kualitas pembelajaran yang tampak dan perolehan hasil evaluasi dan keaktifan siswa. 
Vol. 1 No. 1, Oktober 2017

Dari tabel 4.2 dan gambar 4.2 siklus I hasil observasi menunjukkan, prosentase keberhasilan kelengkapan menyiapkan alat dan bahan percobaan $60 \%$, prosentase keruntutan langkah-langkah yang ditempuh dalam pelaksanaan percobaan $65 \%$, prosentase keaktifan siswa dalam melaksanakan kegiatan percobaan $70 \%$, prosentase keaktifan siswa dalam mengutarakan pendapat saat berdiskusi $68 \%$ dan prosentase hasil penarikan kesimpulan akhir sesuai percobaan $66 \%$.

Berdasarkan tabel 4.5 dan gambar 4.4 siklus II hasil observasi menunjukkan, prosentase keberhasilan metode kelengkapan menyiapkan alat dan bahan percobaan siswa yang disiapkan $80 \%$, prosentase keruntutan langkah-langkah yang ditempuh dalam pelaksanaan percobaan $90 \%$, prosentase keaktifan siswa dalam melaksanakan kegiatan percobaan $90 \%$, prosentase keaktifan siswa dalam mengutarakan pendapat saat berdiskusi $88 \%$ dan prosentase hasil penarikan kesimpulan akhir sesuai percobaan $87 \%$.

Dari daftar nilai (lihat lampiran) dapat kita lihat adanya prosentase kenaikan nilai Bahasa Indonesia mulai dari kondisi awal pra tindakan, diketahui baru 10 siswa atau $33,3 \%$ yang mengalami ketuntasan belajar dan mendapatkan nilai sesuai dengan KKM. Hasil evaluasi siklus I menunjukkan baru 19 siswa atau 63,3\% yang mengalami ketuntasan belajar dan mendapat nilai sama dengan atau di atas KKM yaitu 70. Hal itu menunjukkan bahwa pelaksanaan siklus I belum mencapai keberhasilan, karena indicator pencapaian adalah sebesar $85 \%$ atau lebih. Siklus II menunjukkan ada 28 siswa atau 93,3\% dari 30 siswa yang mengalami ketuntasan belajar. Sehingga peneliti menyimpulkan bahwa pada siklus II ini peneliti telah mencapai keberhasilan dari penelitian tindakan kelas yang telah dilakukan.

Ketika peneliti melaksanakan siklus I, peneliti mengalami berbagai kendala antara lain masih ada siswa yang kesulitan dalam membedakan antara puisi. Masih ada kelompok yang bingung dalam mengikuti langkah-langkah yang tertera dalam lembar kegiatan. Masih ada beberapa siswa yang belum aktif dalam pelaksanaan percobaan. Ketika pelaksanaan diskusi, ada beberapa siswa yang tidak aktif menyampaikan pendapatnya. Dalam menyimpulkan hasil percobaan, terdapat 4 (tiga) kelompok yang malu untuk presentasi, dan hanya terdapat 4 (empat) siswa yang mengajukan pertanyaan.

Peneliti kemudian melaksanakan siklus II sebagai perbaikan siklus I, sebelum pelaksanaan siklus II ini peneliti mengganti rencana pembelajaran Model Pembelajaran Metode Think pair share baru yaitu dengan menulis iklan baris untuk kegiatan sekolah. Dalam pelaksanaan percobaan, peneliti senantiasa memberi bimbingan untuk siswanya dalam melaksanakan langkah-langkah sesuai lembar kegiatan. Peneliti pun memberi bimbingan siswa saat berdiskusi untuk menarik kesimpulan.

Dengan adanya motivasi guru berupa reward, siswa telah terlihat aktif dalam kegiatan pembelajaran dalam melaksanakan percobaan, presentasi di depan kelas dan berdiskusi menarik kesimpulan. Meskipun ada kendala yaitu ada beberapa siswa yang masih belum menggunakan kalimat yang baku untuk menulis iklan baris sehingga suasana menjadi gaduh, namun dengan hasil prestasi belajar yang dicapai dapat disimpulkan bahwa penelitian tindakan kelas dari siklus II ini telah berhasil.

\section{KESIMPULAN}

Penerapan pendekatan Think Pair Share dapat meningkatkan Ketrampilan Menulis Bahasa Indonesia siswa Kelas IX A SMP Negeri 4 Tulungagung. Hal ini dilihat dari prosentase kenaikan nilai Bahasa Indonesia siswa Kelas IX A dari pra siklus, siklus I sampai Siklus II. Pada pra siklus, siswa yang mendapat nilai minimal 70 ada 10 siswa atau $33,3 \%$, pada siklus I siswa yang mendapat nilai minimal 70 ada 19 siswa atau $63,3 \%$, pada siklus II siswa yang mendapat nilai minimal 70 ada 28 siswa atau 93,3\% dari 30 siswa. Dari pra siklus kemudian dilaksanakan siklus I prestasi siswa mengalami prosentase kenaikan 30,0\%. Dan dari siklus I kemudian dilaksanakan siklus II prestasi siswa mengalami prosentase kenaikan 30,0\%.. 
Penerapan pembelajaran dan prosedur dalam penelitian ini didasarkan pada pembelajaran dengan menerapkan pendekatan Think Pair Share dalam pelaksanaan proses pembelajaran Bahasa Indonesia. Model yang dipakai dalam penelitian tindakan kelas ini adalah model siklus, adapun prosedur penelitiannya terdiri dari 2 siklus. Siklus I dilaksanakan pada hari Rabu tanggal 7 September 2016, Kompetensi Dasar 4.1 Menulis iklan baris dengan bahasa yang singkat, padat dan jelas. Serta indikator 4.1.1 Menuliskan objek yang diiklankan dengan ,4.1.2 Menggunakan kata-kata yang sesuai dengan kebiasaan iklan baris. Siklus II dilaksanakan hari Rabu tanggal 14 September 2016.

Dalam setiap pelaksanaan siklus terdiri dari 4 (empat) tahapan, yaitu perencanaan tindakan, pelaksanaan, observasi, dan refleksi, kegiatan ini dilaksanakan berdaur ulang. Sebelum melaksanakan tindakan dalam tahap siklus, perlu perencanaan. Perencanaan ini memperhatikan setiap perubahan yang dicapai pada siklus sebelumnya terutama pada setiap tindakan yang dapat meningkatkan Ketrampilan Menulis siswa. Hal ini didasarkan pada analisis perkembangan dari pra siklus, siklus I sampai siklus II.

Berdasarkan kriteria temuan dan pembahasan hasil penelitian seperti yang diuraikan pada bab IV, maka penelitian ini dapat digunakan peneliti untuk membantu guru dalam menghadapi permasalahan yang sejenis. Disamping itu, perlu penelitian lanjut tentang upaya guru untuk mempertahankan atau menjaga dan meningkatkan Ketrampilan Menulis siswa. Pembelajaran dengan menggunakan pendekatan Think Pair Share ini pada hakikatnya dapat digunakan dan dikembangkan oleh guru yang menghadapi permasalahan yang sejenis, terutama untuk mengatasi masalah peningkatan Ketrampilan Menulis siswa.

Berdasarkan hasil observasi dan pelaksanaan siklus I dan II juga dapat kita amati adanya perubahan kenaikan prosentase dalam menyiapkan alat dan bahan, keruntutan langkah-langkah siswa dalam melaksanakan percobaan, keaktifan siswa dalam melaksanakan kegiatan percobaan, keaktifan siswa ketika berdiskusi dan hasil akhir atau simpulan yang diperoleh dari hasil kegiatan diskusi

\section{SARAN}

Berikut saran yang dapat diajukan berkaitan dengan penelitian ini, untuk melaksanakan pengembangan pembelajaran menggunakan pendekatan Think Pair Share memerlukan persiapan yang cukup matang, sehingga guru harus mampu menentukan atau memilih topik yang benar-benar bisa dikembangkan dengan Pengembangan Pembelajaran menggunakan pendekatan Think Pair Share dalam proses belajar mengajar sehingga memperoleh hasil yang optimal. Dalam rangka meningkatkan kualitas kinerja Guru, guru hendaknya lebih sering melatih Guru dengan berbagai pendekatan pengajaran, walau dalam taraf yang sederhana, dimana Guru nantinya dapat menemukan pengetahuan baru, memperoleh konsep dan keterampilan, sehingga Guru berhasil atau mampu memecahkan masalah-masalah yang dihadapi. Perlu adanya penelitian yang lebih lanjut, karena hasil penelitian ini hanya dilakukan di SMP Negeri 4 Tulungagung semester 1 tahun pelajaran 2016/2017, dan untuk peneltian yang serupa hendaknya dilakukan perbaikan-perbaikan agar diperoleh hasil yang lebih baik.

\section{DAFTAR RUJUKAN}

Abin Syamsuddin Makmun. 2003. Psikologi Pendidikan. Bandung: PT Rosda Karya Remaja.

Buchori M. 1992. Psikologi Pendidikan 3. Bandung: Jeanmars.

Fudyartanto, Ki RBS. 2002. Psikologi Pendidikan dengan Pendekatan Baru. Yogyakarta: Global Pustaka Ilmu.

Gulo. W. 2004. Strategi Belajar Mengajar. Jakarta: PT. Grasindo.

Gunter. 1999. Games for Children. Oxford University Press 
Vol. 1 No. 1, Oktober 2017

Hartina. 2008. Pengaruh Model Pembelajaran Kooperatif Tipe Think Paire Share (Think Pair Share) terhadap Hasil Belajar Kimia Siswa Kelas XI IPA SMA Negeri 5 Makassar (Studi pada Materi Pokok Laju Reaksi). Skripsi. Jurusan Kimia FMIPA, UNM.

Hayinah. 1992. Masalah Belajar, Malang: IKIP Negri Malang.

Ibrahim, dkk. 2000. Pembelajaran Kooperatif. Surabaya: University Press

Lie, Anita. 2002. Cooperatif Learning. Jakarta: PT. Gramedia Widisarana Indonesia

Lie, Anita. 2004. Cooperatif Learning. Jakarta: Gramedia.

Muhibbin Syah. 2003. Psikologi Belajar. Jakarta: PT. Raja Grafindo Persada

Nana Sudjana \& Ibrahim. 1989. Penelitian dan Penilaian Pendidikan. Bandung: Sinar Baru.

Oemar Hamalik. 2003. Kurikulum dan Pembelajaran. Jakarta : Bumi Aksara.

Oemar Hamalik. 2004. Proses Belajar Mengajar. Jakarta : Bumi Aksara.

S. Nasution. 1996. Azas-azas Mengajar, Bandung: Tarsito

Slavin, R. E. 1994. Educational Psychology Theory Into Practices. 4th ed. Boston: Ally and Bacon Publishers.

Tirtonegoro, Sutratinah. 1998. Anak Supernormal dan Program Pendidikannya, Yogyakarta: Bumi Aksara.

W.S.Winkel. 2004. Psikologi Pengajaran. Yogyakarta: Media Abadi 